\title{
HUBUNGAN PRESTASI PRAKEIN SISWA DAN MINAT BERWIRAUSAHA SISWA TKR SMK MUHAMMADIYAH 1 SLEMAN
}

\author{
Anggit Wahyu Nugroho*, Sudiyanto \\ Pendidikan Teknik Otomotif, Universitas Negeri Yogyakarta \\ *Email: anggit1995@gmail.com
}

\begin{abstract}
This study aimed to find out the relationship between internship achievement and entrepreneurial interest among students of light vehicle engineering (LVE) of SMK Muhammadiyah 1 Sleman. This was a correlational study. The research subjects were 70 LVE students at SMK Muhammadiyah 1 Sleman with a total of 70 students. The data were collected using questionnaires and documents. The data were analyzed using product moment statistics. The results of the study showed that the students' industrial internship achievement was $56 \%$ in the good category, their entrepreneurial interest was 53\% in the high category, and there was a relationship between the internship achievement and the entrepreneurial interest among the students of LVE of SMK Muhammadiyah 1 Sleman in the 2018/2019 academic year. The relationship between industrial internship achievement and entrepreneurial interest was classified as a moderate correlation with a Pearson Correlation coefficient of 0.599. The outstanding values were knowledge and expectation of working through entrepreneurship. Meanwhile the weak values were attitude towards and attention to entrepreneurship activities.
\end{abstract}

Keywords: Relationships, Interest, Industrial Internship, Entrepreneurship

\begin{abstract}
Abstrak
Penelitian ini bertujuan untuk mengetahui hubungan antara prestasi prakerin dan minat berwirausaha siswa TKR di SMK Muhammadiyah 1 Sleman. Jenis penelitian ini merupakan penelitian korelasional. Subjek penelitian adalah siswa TKR di SMK Muhammadiyah 1 Sleman sebanyak 70 orang. Pengambilan data menggunakan metode angket dan dokumen. Analisis data menggunakan statistik product momen. Hasil penelitian menunjukan prestasi prakerin siswa sebanyak $56 \%$ masuk dalam kategori baik, minat berwirausaha siswa sebanyak 53\% masuk dalam kategori tinggi, dan terdapat hubungan antara prestasi prakerin terhadap minat berwirausaha siswa TKR SMK Muhammadiyah 1 Sleman tahun ajaran 2018/2019. Hubungan antara prestasi prakerin dan minat berwirausaha tergolong dalam korelasi sedang dengan Pearson Correlation sebesar 0.599. Nilai menonjol adalah pengetahuan dan harapan bekerja dengan berwirausaha. Sedangkan nilai yang masih lemah adalah sikap dan perhatian terhadap kegiatan berwirausaha.
\end{abstract}

Kata kunci: Hubungan, Minat, PRAKERIN, Wirausaha

\section{PENDAHULUAN}

Seiring dengan bertambah pesatnya jumlah penduduk Indonesia di era globalisasi dan industrialisasi menimbulkan banyak permasalahan, salah satunya adalah menyempitnya lapangan pekerjaan. Kesempatan kerja yang ditawarkan lebih sedikit dibandingkan dengan jumlah para pencari kerja. Akibatnya angka pengangguran semakin bertambah dan berdampak pada perekonomian Indonesia. 
Semakin bertambahnya penduduk di Indonesia akan menyebabkan semakin ketatnya persaingan masuk ke dunia kerja (dunia usaha/industri), menurut badan pusat statistik terdapat kenaikan jumlah pengangguran di Indonesia terhitung dari bulan Agustus 2016 sebanyak 7.03 juta orang dan pada Agustus 2017 sebanyak 7.04 juta orang. Ditinjau dari tingkat pendidikan, jumlah pengangguran yang tertinggi ada pada tingkat sekolah menengah kejuruan (SMK) dibandingkan dengan tingkat pendidikan lain, yaitu mencapai 11.41 persen. Bisa jadi salah satu penyebabnya adalah masih adanya mata pelajaran di SMK yang kurang sesuai dengan kebutuhan di Industri (Yudantoko \& Arifin, 2016).

Dalam mata pelajaran produktif siswa diberikan materi teori dan praktik untuk membentuk kompetensi dasar siswa sehingga dapat mengembangkan dirinya sesuai dengan tuntutan perkembangan ilmu pengetahuan dan teknologi, serta memiliki daya penyesuaian (adaptability) yang baik dalam mengikuti berbagai perubahan yang terjadi di dunia kerja (Haryana, Pambayun, Sudiyanto, \& Sutiman, 2018). Pembelajaran produktif adalah program yang dirancang dan dilaksanakan berdasarkan prosedur dan standar bekerja yang sesungguhnya (real job), untuk menghasilkan barang atau jasa sesuai permintaan pasar. Selain merupakan media belajar menghadapi pekerjaan, pelajaran produktif juga berfungsi untuk menanamkan pengalaman produktif dan mengembangkan sikap wirausaha, melalui pengalaman langsung memproduksi barang atau jasa. Tidak hanya melakukan prkatik pekerjaan di sekolah, program pelajaran produktif diusahakan dapat dilaksanakan di dunia kerja agar siswa dapat mempelajari dan menerapkan sikap, sistem nilai, dan etos kerja yang dituntut oleh dunia kerja.

Dengan pelajaran produktif sebagai modal awal PRAKERIN, harapannya siswa mampu secara cepat beradaptasi dengan dunia kerja sesuai dengan bidang yang ditekuni. Prestasi dan pengalaman PRAKERIN tersebut diharapkan akan berhubungan terhadap minat siswa untuk berwirausaha. Prestasi dan pengalaman PRAKERIN yang didapat dengan baik akan menjadikan tingginya minat berwirausaha siswa dan sebaliknya.

Berdasarkan hasil observasi yang telah dilakukan di SMK Muhammadiyah 1 Sleman, PRAKERIN dilaksanakan selama 2 bulan terhitung dari tanggal 02 Januari 2018 sampai 03 Maret 2018. Pada tahun ajaran 2017/2018 terdapat 70 orang siswa kelas XI dari program kompetensi keahlian teknik kendaraan ringan (TKR) yang melaksanakan kegiatan PRAKERIN. Menurut ketua program kompetensi keahlian otomotif, pelaksanaan PRAKERIN masih belum maksimal, mulai dari tahap awal hingga akhir. Pasalnya siswa dengan bebas memilih tempat yang hendak mereka gunakan untuk melaksanakan PRAKERIN baik secara mandiri maupun berkelompok, hingga sekarang belum ada standar bengkel yang harus dipenuhi agar dapat dijadikan sebagai tempat pelaksanaan PRAKERIN. 
Mekanisme dalam penilaian siswa selama melaksanakan PRAKERIN merupakan nilai laporan, pengetahuan, dan sikap. Nilai pengetahuan dan sikap diberikan oleh dunia kerja dan nilai laporan diberikan oleh guru pembimbing, nilai akhir dari PRAKERIN ini adalah akumulasi dari nilai laporan, pengetahuan, dan nilai sikap. Tapi dengan latar belakang industri yang berbeda-beda dapat menyebabkan penilaian dalam hal kinerja siswa selama melaksanakan PRAKERIN menjadi kurang akurat, maka dari itu monitoring dan pemantauan terus dilakukan oleh guru pembimbing dan kordinator PRAKERIN. Setiap tahunnya ada siswa yang berpindah tempat PRAKERIN yang dikarenakan oleh berbagai faktor, salah satunya dan yang paling banyak adalah siswa lebih memilih bengkel atau industri yang cenderung lebih sepi dengan alasan kelelahan, dan masih ada siswa yang ketahuan membolos saat PRAKERIN berlangsung.

Sehubungan dengan uraian di atas, penelitian dilakukan pada kelas XII program kompetensi keahlian TKR SMK Muhammadiyah 1 Sleman tahun ajaran 2018/2019, dikarenakan siswa kelas XII telah terjun ke dunia kerja guna melaksanakan PRAKERIN. Serta pentingnya penelitian ini adalah dapat mengetahui bagaimana hubungan antara prestasi PRAKERIN siswa kelas XII program kompetensi keahlian TKR dengan minat siswa dalam berwirausaha.

Dari hasil wawancara dengan ketua program kompetensi keahlian otomotif beliau membahas banyak lulusan dari siswanya yang bekerja tidak sesuai dengan bidang keahliannya. Dari data penelusuran siswa tamatan yang ada disekolah menunjukan bahwa dari 58 orang lulusan program kompetensi keahlian TKR SMK Muhammadiyah 1 Sleman tahun 2016/2017 hanya 29 orang yang bekerja, sedangkan 29 orang lulusan lainnya belum bekerja dan tidak melanjutkan ke jenjang selanjutnya atau mengangur. Beliau juga mengatakan dari 29 orang lulusan yang bekerja tersebut hanya 1 sampai 3 orang saja yang bekerja sesuai dengan bidang keahlian mereka, sebagian besar lulusan bekerja sedapatnya saja dan tidak sesuai dengan bidang yang mereka pelajari dan mereka tekuni sewaktu di sekolah.

Berdasarkan hasil observasi yang dilakukan mengenai minat berwirausaha siswa kelas XII, dari pihak sekolah belum mempunyai data dan informasi mengenai minat berwirausaha siswa kelas XII. Akibat dari data yang tidak ada itu dapat mengakibatkan penanganan dan pengarahan bagi siswa yang ingin bekerja ataupun berwirausaha menjadi kurang tepat. Memupuk minat siswa untuk berwirausaha sejak dini merupakan hal yang penting, mengingat semakin sempitnya lapangan pekerjaan di era ini, sesuai dengan tujuan dari sekolah menengah kejuruan yaitu untuk mendidik siswanya agar dapat langsung bekerja atau berwirausaha setelah lulus. Informasi dari penelitian ini akan sangat berguna bagi siswa untuk terus mengembangkan minat berwirausaha mereka dan bagi sekolah untuk mengevaluasi pelaksanaan pembelajaran 
serta mempersiapkan siswanya untuk langsung bekerja di dunia kerja maupun berwirausaha sejak dini.

\section{METODE PENELITIAN}

Desain Penelitian yang digunakan dalam penelitian ini adalah korelasional. Penelitian ini menggunakan jenis pendekatan kuantitatif. Dipilihnya pendekatan kuantitatif pada penelitian ini karena dalam proses memperoleh data yang digunakan berupa angka sebagai alat untuk menemukan keterangan mengenai apa yang diteliti. Penelitian ini bertujuan untuk mengetahui hubungan prestasi prakerin dan minat berwirausaha siswa kelas XII jurusan teknik kendaraan ringan SMK Muhammadiyah 1 Sleman.

Penelitian ini termasuk dalam jenis penelitian Ex-Post Facto. Menurut Sukardi (2003:165), "Penelitian Ex-post Facto merupakan penelitian yang tidak dibuat perlakuan terhadap variabel-variabel penelitian". Penelitian ini hanya meneliti apa yang sudah ada pada diri responden.

Subjek penelitian ini adalah siswa kelas 12 TKR SMK Muhammadiyah 1 Sleman berjumlah sebanyak 70 siswa. Kelas XII TKR dipilih karena kelas tersebut dianggap sudah memiliki bekal yang cukup dari sisi keilmuan dan pengalaman di bidang kendaraan ringan dibandingkan dengan kelas XI dan kelas X. Sehingga kelas XII dianggap layak untuk dijadikan subjek penelitian ini. Teknik pengumpulan data yang digunakan dalam peneitian ini adalah menggunakan metode angket dan dokumentasi. Angket digunakan untuk mendapatkan data tentang minat berwirausaha siswa dengan mengajukan pernyataan atau pertanyaan tertulis. Dokumentasi digunakan untuk mendapatkan data tentang prestasi prekerin.

Untuk menganalisis data yang didapatkan, digunakan teknik analisis product momen. Menurut Sugiyono (2015:274) Antara prestasi PRAKERIN dengan minat berwirausaha dapat dihitung korelasinya menggunakan rumus product momen. Data yang didapatkan tersebut kemudian dianalisis agar didapat hasil akhir berupa keeratan hubungan antara prestasi prekerin dan minat berwirausaha siswa.

\section{HASIL PENELITIAN DAN PEMBAHASAN}

\section{Hasil Penelitian}

Berdasarkan hasil penelitian yang telah dilakukan mengacu pada data nilai prakerin dan jawaban angket mengenai minat berwirausaha siswa kelas XII teknik kendaraan ringan di SMK Muhammadiyah 1 Sleman, maka diperoleh data berupa data kuantitatif yang telah dianalisis, adapun hasil analisis tersebut adalah sebagai berikut.

Tabel 1.Hasil Prestasi Prakerin Siswa 


\begin{tabular}{cccc}
\hline No & Kualifikasi & Jumlah Siswa & \% \\
\hline 1 & Sangat Baik & 19 & $27 \%$ \\
2 & Baik & 39 & $56 \%$ \\
3 & Cukup & 12 & $17 \%$ \\
\hline
\end{tabular}

Tabel 2. Kesiapan kerja berdasarkan ciri-ciri

\begin{tabular}{llcc}
\hline No & \multicolumn{1}{c}{ Kategori } & Jumlah Siswa & \% \\
\hline 1 & Sangat Tinggi & 12 & $17 \%$ \\
2 & Tinggi & 37 & $53 \%$ \\
3 & Rendah & 18 & $26 \%$ \\
4 & Sangat Rendah & 3 & $4 \%$ \\
\hline
\end{tabular}

\section{Pembahasan}

Berdasarkan hasil pengolahan data yang telah dilakukan didapatkan, penelitian ini bertujuan untuk mengetahui prestasi PRAKERIN, minat berwirausaha, serta hubungan antara prestasi PRAKERIN dan minat berwirausaha kelas XII kompetensi keahlian TKR SMK Muhammadiyah 1 Sleman tahun ajaran 2018/2019. Dari data yang telah diperoleh kemudian dilakukan analisis dan dilakukan pembahasan tentang hasil penelitian sebagai berikut. Secara keseluruhan hasil penelitian menunjukkan bahwa tingkat kecenderungan prestasi PRAKERIN termasuk dalam kulalifikasi baik dengan 56\% siswa, aspek pengetahuan yang menonjol dan aspek sikap yang masih lemah. Tingkat kecenderungan minat berwirausaha termasuk dalam kualifikasi tinggi dengan 53\% siswa, aspek harapan bekerja dengan berwirasaha yang menonjol dan aspek perhatian terhadap kegiatan berwirausaha yang masih lemah. Hubungan antara prestasi PRAKERIN dan minat berwirausaha siswa kelas XII kompetensi keahlian TKR SMK Muhammadiyah 1 Sleman didapatkan hubungan yang positif dan signifikan. Melalui uji korelasi diperoleh nilai korelasi (r) sebesar 0.599 dan termasuk dalam kategori korelasi sedang dan hampir menuju korealasi kuat. Berdasarkan penjelasan di atas maka dapat dikatakan bahwa semakin tinggi prestasi PRAKERIN, maka akan semakin tinggi pula minat berwirausaha siswa.

Berdasarkan hasil analisis menunjukkan bahwa terdapat hubungan positif dan signifikan antara prestasi PRAKERIN terhadap minat berwirausaha siswa kelas XII kompetensi keahlian TKR SMK Muhammadiyah 1 Sleman tahun ajaran 2018/2019. Prestasi PRAKERIN menjadi faktor yang penting dalam menghubungani minat berwirausaha siswa dan hal tersebut sesuai dengan tujuan dari PRAKERIN yang telah dijelaskan pada bab II yaitu : Menghasilkan tenaga kerja yang memiliki keahlian yang professional, yaitu tenaga kerja yang memiliki tingkat pengetahuan, keterampilan, dan etos kerja yang sesuai dengan tuntutan lapangan kerja; Memperkokoh Link and Match kesesuaian kecocokan antara program sekolah dengan tuntutan dunia kerja; Meningkatkan efesiensi proses pendidikan dan pelatihan tenaga kerja yang 
berkualitas/professional; Memberikan pengakuan dan penghargaan terhadap pengalaman kerja sebagai proses pendidikan dan sebagai pembelajaran siswa untuk memulai berwirausaha.

Hal ini juga di dukung oleh pendapat Nurbaya (2012) yang menyatakan bahwa kerja sama antara sekolah dengan dunia usaha akan memberikan pengalaman berwirausaha bagi siswa. Hal ini menunjukan bahwa dengan adanya paktik industri siswa menjadi percaya diri dan siap menjadi wirausaha. Dengan demikian untuk meningkatkan minat berwirausaha siswa di SMK Muhammadiyah 1 Sleman maka variabel Prestasi PRAKERIN perlu lebih ditingkatkan, jadi faktor tersebut akan menentukan tingkat minat berwirausaha siswa.

\section{SIMPULAN}

Dalam pembahasan didapatkan rata-rata prestasi PRAKERIN siswa termasuk dalam kategori baik. Aspek yang berpengaruh adalah aspek pengetahuan dan aspek yang masih lemah adalah aspek sikap. Rata-rata minat berwirausaha siswa termasuk dalam kategori tinggi. Aspek yang berpengaruh adalah aspek harapan bekerja dengan berwirausaha dan aspek yang masih lemah adalah aspek perhatian terhadap kegiatan usaha. Didapatkan hubungan yang positif dan signifikan antara prestasi PRAKERIN dan minat berwirausaha siswa kelas XII kompetensi keahlian TKR SMK Muhammadiyah 1 Sleman tahun ajaran 2018/2019. Hasil Pearson Correlation sebesar 0.599 dan masuk dalam derajat korelasi sedang. Didapatkan pula persamaan regresinya $\mathrm{Y}=33.335+13.706 \mathrm{X}$ yang artinya bahwa setiap kenaikan prestasi PRAKERIN sebesar 1 (satu) akan menambah minat berwirausaha sebesar 13.706.

Prestasi PRAKERIN dapat menimbulkan minat berwirausaha bagi siswa. Dengan diketahuinya prestasi PRAKERIN, maka dapat dilihat kencenderungan siswa untuk berwirausaha. Semakin tinggi prestasi PRAKERIN yang dimiliki oleh siswa maka minat berwirausaha juga akan semakin besar.

Sekolah dapat meningkatkan pelaksanaan PRAKERIN agar prestasi PRAKERIN masuk dalam kategori sangat baik dan minat berwirausaha siswa juga dapat mencapai tingkat yang optimal menjadi sangat tinggi. Sekolah dapat mengoptimalkan aspek yang masih lemah yaitu aspek sikap dan perhatian terhadap kegiatan usaha, sehingga kedua aspek yang masih lemah tersebut menjadi lebih baik.

\section{DAFTAR PUSTAKA}


Haryana, K., Pambayun, N. A. P, Sudiyanto, \& Sutiman. (2019, November). Mapping The Graduate Quality Of Automotive Engineering Education (S1) Study Program FT UNY. In Journal of Physics: Conference Series (Vol. 1273, No. 1, p. 012034). IOP Publishing.

Nurbaya, S. (2012) Faktor-Faktor Yang Mempengaruhi Kesiapan Berwirausaha Siswa Smkn Barabai Kabupaten Hulu Sungai Tengah Kalimantan Selatan. Jurnal UNY, vol. 21.

Sukardi. (2003). Metodologi Penelitian Pendidikan Kompetensi dan Praktiknya. Yogyakarta : Bumi Aksara.

Sugiyono. (2015). Statistika Untuk Penelitian. Bandung : Alfabeta.

Yudantoko, A., \& Arifin, Z. (2016). Profil kompetensi dunia kerja bidang perbaikan bodi otomotif dan tingkat relevansinya dengan dunia pendidikan. Jurnal Pendidikan Vokasi, 6(2), 127-142. 
92 Anggit Wahyu Nugroho 